Article

\title{
Bringing Gender In? EU Foreign and Security Policy after Brexit
}

\author{
Toni Haastrup ${ }^{1, *}$, Katharine A. M. Wright ${ }^{2}$ and Roberta Guerrina ${ }^{3}$ \\ ${ }^{1}$ Division of History \& Politics, University of Stirling, Stirling, FK9 4LA, UK; E-Mail: toni.haastrup@stir.ac.uk \\ 2 School of Geography, Politics \& Sociology, Newcastle University, Newcastle, NE1 7RU, UK; \\ E-Mail: katharine.a.m.wright@newcastle.ac.uk \\ ${ }^{3}$ School of Sociology, Politics \& International Studies, University of Bristol, Bristol, BS8 1TU, UK; \\ E-mail: roberta.guerrina@bristol.ac.uk \\ * Corresponding author
}

Submitted: 3 March 2019 | Accepted: 17 July 2019 | Published: 16 September 2019

\begin{abstract}
In this article, we identify Brexit as a critical process, wherein the EU has had the opportunity to reflect on and reinforce its identity, as a promoter of gender issues within the security domain. It draws on this identity from a foundational myth of the EU as gender equality polity, resulting in the creation of a socio-legal order and sustained discourse on gender inclusivity in all policy areas. Existing scholarship has drawn attention to the EU's particular success in gender equality promotion in the areas of social inclusion at member state level, including in the UK. But, is the EU's reach comprehensive beyond this policy sphere? We examine the ways in which gender is manifested in the area of foreign policy, an area where the UK has consistently shown some leadership on the integration of gender perspectives in its foreign policy through its international development programmes and the implementation of the Women, Peace and Security agenda. It is therefore timely to consider what impact Brexit has on EU policies, practices and the promotion of gender equality in this policy domain. Using a critical feminist lens, this article looks at the evolution of gender equality as a dimension of EU foreign and security policy in the context of EU-UK relations, and the divergences, opportunities and constraints that are crystallised by the Brexit process.
\end{abstract}

\section{Keywords}

Brexit; critical feminism; EU; foreign policy; gender; gender equality; UK; women's agency

\section{Issue}

This article is part of the issue "The Impact of Brexit on EU Policies", edited by Ferdi De Ville (Ghent University, Belgium) and Gabriel Siles-Brügge (University of Warwick, UK).

(C) 2019 by the authors; licensee Cogitatio (Lisbon, Portugal). This article is licensed under a Creative Commons Attribution 4.0 International License (CC BY).

\section{Introduction}

A significant body of literature has emerged examining the impact of the UK's departure from the EU on gender equality. This has highlighted the deeply gendered nature of both current debates and the Brexit process itself. This has found Brexit to be reflective of the continued marginalisation of women as political actors, especially as experts and commentators (Galpin, 2018), and in academic debates (Guerrina, Haastrup, et al., 2018). As such, we are witnessing the 'paradox of men's dominance of the Brexit campaign and women's rise in the political cri- sis' (Hozić \& True, 2017, p. 271). This political moment thus necessitates closer engagement, drawing on critical feminism, of the impact of Brexit on the socio-economic fabric of the country but also Europe more generally.

A number of reports have warned that Brexit jeopardises the political commitment to women's human rights protection in the UK (Equality and Human Rights Commission, 2018). Brexit will also have an impact on the recourse UK civil society have to inter-European networks and funding (Danisi, Dustin, \& Ferreira, 2017; Ritch, 2019). This includes UK civil society actors who have taken an active role in supporting the EU's engagement 
in gender-sensitive foreign policy through the Women, Peace and Security (WPS) agenda, for example, the UK based Gender Advocacy for Peace and Security.

So, the literature clearly indicates that Brexit will likely have a negative impact on the domestic gender equality order in the UK if specific guarantees are not embedded in the Withdrawal Agreement (see Fagan \& Rubery, 2018; Plomien, 2018). However, we know far less about the implications of Brexit on the EU's commitments and practices of gender equality, especially when we look beyond the area of social rights. This represents a significant gap in the literature and speaks to the fluid nature of Brexit itself (see De Ville \& Siles-Brügge, 2019). Examining the impact of the process of Brexit on the prospects of the EU as a gender equal polity is important because it contributes to broader discussions concerning the influence of disintegration and integration as gendered processes (Lombardo, 2018); gender equality is after all an important part of the foundational myths of the EU (MacRae, 2010). Particularly important is the platform provided by the EU for civil society organisations. National advocacy groups feed into European wide umbrella organisations, for example, the European Women's Lobby and European Peacebuilding Liaison Office. This allows for sharing of best practice, norm diffusion and informal processes of Europeanisation to take place (see also Van Eerdewijk \& Roggeband, 2014).

To date the negotiations to determine the aftermath of the UK's departure from the EU have shown a general lack of concern for gender equality provisions or acknowledgement of the gendered implications of post-Brexit EU or UK (Guerrina, 2019). In the throes of Brexit, we see the lack of consideration for gender as an overarching priority as indicative of the limitations of recent EU practices. At the same time, by moving beyond an analysis that limits gender equality to social policies and politics, to engage foreign and security policies, we explore the developments since June 2016 as indicative of the shape of the EU's engagement with gender in the external sphere in the context of, and after, Brexit (O'Dwyer, 2018).

In the aftermath of the 2016 referendum result that is intended to deliver Brexit, European institutions have made specific efforts to better promote the idea of Europe, its norms, and role in global politics through its foreign policies and practices. This is evidenced by the immediate move to implement the Global Strategy soon after the results (see also Nadibaidze, 2019). The lack of consensus as to the future of the internal project, increasing efforts to 'secure' European external borders, has gone hand-in-hand with a re-articulation of the organisation's core values and its role as an external actor. Increasing efforts by the EU to consolidate work on WPS and the Gender Action Plan will be defined by the Brexit paradox. Whereas the UK has relegated issues relating to gender and social justice to the bottom of the policy agenda as it seeks to establish itself as a 'masculinised' great power, the EU for its part has the opportunity to raise the WPS agenda higher up the policy agenda as it seeks to re-affirm its position as a normative power in global politics (Guerrina, Haastrup, et al., 2018; Guerrina \& Masselot, 2018; Kronsell, 2016a; MacLeavy, 2018; Williams, 2017; see also Achilleos-Sarll \& Martill, 2019).

This article develops its analysis in five sections. First, we show how by drawing on a critical feminist approach we are able to shed light on the ways in which gender perspectives are (under)deployed as part of the EU's Brexit landscape thus far. Subsequently, we look at the context of Brexit to justify our interrogation of this particular area of policy. While the third section examines the trajectory of gender equality perspectives in the foreign policy approaches of the EU and the UK, thus opening a space for assessing the impact of the relationships between the UK as a member state and the EU in Section 4. Finally, in Section 5, we examine post-referendum developments in the EU focusing on the development of the Strategic Approach to WPS adopted in December 2018. We conclude with some preliminary thoughts on what this (post-) Brexit space may mean for the practices of an EU common foreign, defence and security policy that takes gender issues seriously.

\section{A Critical Feminist Approach}

The literature has thus far established that the EU often makes claims to be a gender equal polity and a promoter of gender equality norms abroad. However, it is one which embodies a neoliberal market logic (Muehlenhoff, 2017). The inclusion of equal rights between men and women by the EU in the internal sphere was not motivated by feminists concerns of social justice. Rather, the addition of gender equality was solely motivated by economic concerns, specifically to safeguard competition in the new Common Market (Bain \& Masselot, 2012; Kantola, 2010). It is perhaps unsurprising then that this functionalist logic has 'spill-over' into approaches seeking to integrating gender into foreign and security policy. Given this context, we do not assume that the way the EU approaches the inclusion of gender is motivated by feminist goals. At the same time, we cannot deny the EU has (at times) had a role in ensuring gender equality remains on the agenda of some of its member states. As Walby (2004) argues, the EU has been a leader in this area well ahead of most of its own member states. Fagan and Rubery (2018, p. 298) further note three dimensions to the EU's gender equality policy: 'the gender equality regulatory framework (hard law), the gender mainstreaming of...policy formation (guidelines and policy processes) and funding policies (European social funds)'. In the 1970s the UK's equalities legislations were directly prompted by the EU's hard law proposal. More recently, soft law mechanisms such as gender mainstreaming also influenced New Labour's progressive agenda especially in the area of social policy. So, whereas we accept that the EU is a gender actor, we do not assert that it is a feminist actor. 
In this article, we take an explicit feminist approach that is critically reflective about what kind of institution the EU is in order to better understand its processes, and their implications for different marginalised groups. We use a critical feminist approach to unpack how the WPS agenda is being understood by the EU, the role of different actors in driving this agenda within the EU. This is the most appropriate framework because 'a critical approach is based in the intentions of the researcher to transform conditions of inequity and so this stance pervades all aspect of the research process' (Willis et al., 2008). This then informs the entirety of our contribution here.

We draw from a tradition of feminism that acknowledges the endemic nature of gender subordination in society and institutions within it. While gender goes beyond women, the construction of gender is often tied to masculinised and feminised bodies. Critical feminism, by taking into account the 'the ideational and material manifestations of gendered identity and gendered power in world politics' (Sjoberg, 2010, p. 3) helps us understand the ways in which the feminized is subordinated to the masculinized (see also MacKinnon, 1987). Moreover, and as Susan Wright notes, a critical feminist approach takes account of the 'social, cultural and political conditions' (Brexit) under which gender is understood and being done (Wright, 2010, p. 193). Critical feminism in this context further elaborates on the gendered ways in which the voices of traditionally marginalised groups and perspectives continue to be silenced from the Brexit processes (Emejulu, 2016; Haastrup, Wright, \& Guerrina, 2016; Virdee \& McGeever, 2017). Such an approach is all the more salient given, as we highlight, our own relationship with the institution we are studying as 'critical friends'. It also informs our approach to studying it through the use of critical content analysis. This approach, as one underpinned by feminist praxis, enables us to grasp the broader implications of Brexit as a process and the resulting implications for the value placed on gender in the EU's approach to foreign policy. In other words, the article also unpacks how gender is located within the EU's foreign and security matrix. As critical scholars we do not 'take the world as we find it' as problem-solving approaches do (Cox, 1981, pp. 128-129). Rather, we call these institutions into question and account for the possibility of their change (Wright, Hurley, \& Gil Ruiz, 2019, p. 6). In doing so, our research is normatively guided (Cox, 1981, p. 129).

To date, existing research has shown the tendency of both the EU, and EU Studies more broadly, to marginalise gender issues (Guerrina, Haastrup, et al., 2018) outside of the areas we have identified. Moreover, there has been very little feminist attention paid to the security dimension. Where this has been the case (see Guerrina, Chappell, \& Wright, 2018; Guerrina \& Wright, 2016; Haastrup, 2018; Kronsell, 2016b) an explicit feminist institutionalist account has been prioritised. However, in the context of Brexit and while the institutionalist lens pro- vides useful lessons, it is not particularly useful to apply here given the ways in which Brexit remains in flux-the rules of game are not set. Rather, to transform our subject of study (gender in foreign and security policies) and understand it in particular contexts (Brexit), we seek to explicitly politicise and unpick the ways in which inequalities and differences are manifested (Henry, 2018, p. 2). Ultimately our approach provides an important counternarrative to mainstream analysis of Brexit and indeed the EU's foreign and security policy approach.

As a member state, the UK has been tied to the EU's processes. It is thus unsurprising that the EU has had an important role in shaping the UK's commitment to gender equality (Hantrais, 2018). The UK's entry into the European Economic Community in January 1973, came at a time of expansion for gender equality provisions in the treaties. European legislation has influenced the development of national equality policies (see Annesley \& Gains, 2013). However, the UK's implementation of EU gender norms is not uncontested as we see in the UK's preference for de-regulation, limiting the scope of the 1992 Pregnant Workers' Directive (Guerrina, 2005). Overall, given this history, and despite the disentangling of the legal framework, civil society groups and feminists organisations expected the principle of gender equality and some gender sensitivity to be fundamental to the Brexit process (Guerrina \& Masselot, 2018). Specifically, there was an expectation that gender issues would be included in the referendum, post referendum, negotiation processes and in the context discussions on the UK's future relationship with the EU. In particular given both the UK and EU's public statements and wider commitment to the WPS agenda which calls for the mainstreaming of gender into the realm of foreign policy.

\subsection{A Note on Methodology}

Drawing on the work of Wright et al. (2019) and Holvikivi (2019) we position ourselves as researchers as 'critical friends' to the institution we are studying. Our approach is underpinned by feminist praxis which necessitates us to engage in ongoing process of reflexivity (Holvikivi, 2019, p. 132; Wright et al., 2019, p. 6). As scholars of EU foreign policy with gender expertise we have been invited to meetings in Brussels has and have thus benefited from privileged access and insight into the day-today challenges of doing gender work, and these experiences frame our interpretation of key policy frameworks. Moreover, as Holvikivi (2019) argues, this makes it difficult to maintain 'neat distinctions between researcher and researched'.

This article brings together a number of different methodological approaches. We have drawn on our discussions with individuals located inside and outside the EU who have been involved in developing the Strategic Approach, participant observation, including of consultations on the new WPS action plan at both member state and EU levels, and critical content analysis of key policy 
documents. Our discussions occurred under conditions of anonymity and as such we do not directly quote them here. However, they have proved valuable for identifying focal points for our analysis more broadly.

A critical approach to content analysis means that 'the researcher uses a specific critical lens as the frame from which to develop the research questions and to select and analyze the texts' (Short, 2016). In this context, we examined the Withdrawal Agreement and political declaration; UK government documents such as the National Action Plans (NAPs) on WPS; and EU documents, including the Gender Action Plan to formulate questions to ask of the new EU Strategic Approach to WPS. Where appropriate, we supplemented these with abbreviated minutes from meetings. We undertook computer-aided critical content analysis of the Strategic Approach using NVivo software. NVivo assists us with creating a systematic analysis of documents and helps to aid crosscheck coding.

Applying critical content analysis means 'thinking with theory' and differentiates this approach from other types of textual analysis (Utt \& Short, 2018). It means going further than applying a theoretical framework to an analysis of content. Rather, the 'method demands that authors deeply know, understand, and live the theoretical approaches they are taking up' (Utt \& Short, 2018, p. 3). In this way theory too becomes part of the whole research process, rather than as an add on to analyse results or just to frame research questions.

From the moment that the referendum was declared, and campaigning started, many scholars noted the glaring absence and consideration of a gender analysis. In the first instance, there was the absence of women in the debates about Brexit. This was obvious in the UK context. This is significant in so far as representation matters. Linked to the physical absence of women was the neglect of women's perspectives on core issues that then came to dominate the debates: including trade, defence and security policies, and immigration. When the absence of women became more noticeable however, much of the discourse reverted back to those areas where the EU had showed obvious competence and those traditionally perceived of as lower order 'soft' issues: for example, social policy.

This model of erasure was unfortunately replicated once negotiations between the UK and the EU commenced. For feminist scholars, despite the deeply gendered domain within which Brexit has been taking place, the importance of inclusion especially the inclusion of women and other marginalised groups has either been downgraded or completely ignored. The lack of consideration of gender is relevant for Brexit since the process has intended outcomes. To what extent are those outcomes gender-sensitive for the EU? To what extent is gender expertise lost due to the impending and eventual separation at the EU level? None of these essential questions have been asked thus far. This is particularly significant since the most recent crisis, the 2008 financial crisis, has shown overwhelmingly that government responses across the Union, and preparations were gendered, with clear negative implications for women.

In this article, we ask and seek to answer these questions and within a particular policy, foreign and security policy. Understandably, the majority of Brexit concerns have been about the relationship between the UK and the EU going forward. But as with the UK, there is life after Brexit for the EU too. The discourse underpinning the main site of 'doing' Brexit so far, the negotiations, emphasises 'deal-making' as conflictual in nature which has served to inhibit inclusion of consideration of the gender impact of Brexit (Achilleos-Sarll \& Martill, 2019), including on the EU. Moreover, security and defence are taken for granted as an area of cooperation that will continue between UK and EU. Significantly however, in parallel to Brexit, both the UK and EU have reemphasised their commitment to the implementation of the WPS agenda as a part of foreign policy. In the following section then, we explore the ways in which the UK within the EU has understood this nexus between security/defence and gender so as to understand the implications that the process of leaving has had on the EU's implementation of this nexus since the referendum.

\section{Gender in Foreign Policy: How Has the UK Contributed to Europe?}

From the UK perspective, the Brexit negotiations have been underpinned by a narrative promoting Britain's assumed global role in the world (Achilleos-Sarll \& Martill, 2019). This has relied on a discourse of militarism and has emphasised 'strength, security and global power' (Achilleos-Sarll \& Martill, 2019). While feminist researchers see clear gendered implications, this new global outlook has been treated as gender-neutral. The UK of course often claims leadership in the area of human rights that emphasises women's rights. This has developed into a projection of a global expertise that increasingly includes women's rights as a leitmotif of its foreign policy practice in recent years. For example, under Conservative Justine Greening leadership of the Department for International Development, the ministry launched the Girls Education Challenge in 2012. This ambitious multi-year, multi-country program is worth about 455 million pounds and is a 12-year commitment by the government to improve educational opportunities for the most marginalised girls in countries in Africa and Asia.

Beyond its role in international development, the UK has become a norm entrepreneur with the Preventing Sexual Violence in Conflict Initiative (PSVI) as part of its commitment to the global WPS Agenda. The WPS agenda encapsulated in UN Security Council Resolution 1325 adopted in 2000 and the seven follow-up resolutions has introduced gender concerns to international security. It calls for both the better participation of women in the area of peace and security, and also acknowledges they 
are disproportionately impacted by conflict. The adoption of UNSCR 1325 was ground-breaking. Since its adoption states have sought to develop NAPs for the implementation of the agenda, and the UN and regional organisations (including the EU) have also sought to support the implementation of WPS. To date, the UK has adopted four NAPs and is a penholder for WPS, meaning that it has the informal role of initiating and drafting relevant documents in this policy area within the UN Security Council, further underscoring this leadership. PSVI was spearheaded by former Foreign Secretary William Hague. It set in motion an international regime which has consequences for perpetrators (criminal prosecutions) and survivors (recognition, justice and support; Davies \& True, 2017).

These NAPs tell us something about how, pre-Brexit, the UK positioned gender issues in its role as an EU member state. In the first NAP (2006), the UK already commits to what becomes the PSVI programme. However, there is no mention at all of the EU. In the second NAP (2010-2013), the UK commits to encouraging the European Commission to build WPS issues into EU Country Strategies and National Indicative Plans'. It makes the same commitment to support the Organisation for Security Cooperation in Europe. This is part of its broader multilateral strategy to lead globally on preventing sexual violence in conflict and building capacity for women mediators in Europe and beyond. Further, successive NAPs have shown that the UK does see its role as a member state of the EU, in promoting the WPS agenda by leveraging its experiences to develop collective European approaches to WPS implementation.

Since the 2016 Referendum, the UK has continued its support for the EU's work on WPS and has been more visible in this context. For example, in March 2019 the UK helped to facilitate a high-level conference in Bosnia Herzegovina on WPS in the Western Balkans (European Union, 2019). This came about as part of the UK's broader efforts to facilitate EU-NATO cooperation, leading to the EU 'adopting' Bosnia Herzegovina to support its efforts to develop its own WPS strategies. Moreover, in January 2019 the UK facilitated an EU-NATO-UN workshop in London on preventing sexual exploitation and abuse (Marinaki, 2019). The UK's engagement in these arenas underscores the commitment to multilateral approaches and engagement through regional security institutions, including the EU and NATO, specifically on WPS. It is worth highlighting however that the UK's approach to WPS tends towards the valorisation of militarism. This enthusiasm for leading within NATO, including hosting the high-level NATO meeting in December 2019, captures this perfectly. Such an approach to WPS sits uncomfortably with the WPS agenda more broadly and seemingly in opposition to the EU, an institution that discursively at least claims to have a different approach to security.

In the context of Brexit, the UK is finding its place again as an international actor. That the UK has sought to foster engagement between the EU and NATO on WPS is interesting given obvious implications for European foreign and security policies. It raises the question of whether the UK is positioning WPS as an area of common interest with the EU post-Brexit. We know that WPS has been used by other actors as a 'non-contentious' issue to foster relationships with otherwise divergent actors, e.g., Sweden and NATO (Wagnsson, 2011; Wright, 2016), NATO and Japan (Wright et al., 2019). The EU has also prioritized it in some select partnerships (Haastrup, 2017). It could therefore be used instrumentally to foster closer UK-EU relations post-Brexit. The next section will explore the impact of Brexit on the EU's role as a global gender actor. In so doing, it draws attention to the two-way relationship between international organisations and their member states in advancing the WPS agenda at times of crisis.

\section{Gendering EU Foreign \& Security Policy: Brexit Edition}

In the EU, the inclusion of gender equality or a gender perspective into foreign policy or external relations came via its development policies. In this area, the inclusion of gender is relatively uncontroversial for the institution. As analysis of EU practices in these areas have shown gender is understood instrumentally, within a neoliberal context whose primary purpose is to support economic development, rather than a goal in and of itself (Debusscher, 2011). Gender perspectives have therefore reinforced, rather than substantively challenged, the EU's existing approach to development.

In the period between 2000 and 2016, where we see the opportunity to implement the WPS agenda, we observe that the EU is absent, as a distinct actor, in an otherwise natural role. Ostensibly then, the UK's leadership did not galvanise EU level action. It was not until 2008, via the Comprehensive Approach to the EU Implementation of the United Nations Security Council Resolution 1325 and 1820 on Women, Peace and Security and the Implementation of UNSCR 1325 as Reinforced by 1820 in the Context of ESDP that the initial link was made between gender and security policy in the EU context. Overall, we find similar patterns in the field of security as in development (see Guerrina \& Wright, 2016; Muehlenhoff, 2017).

In 2016 however, just after the Brexit referendum, the EU set out its updated foreign policy framework via the EU Global Strategy (EUGS). In it, the EU reiterated its firm commitment to integrating measures towards gender equality in its foreign and security policies. The message is supposed to be clear, that gender issues are essential to the EU's foreign policy architecture and practices. Before 2016, this idea was leveraged in EU external relations with third parties (see Haastrup, 2017, p. 208). Yet, how exactly to implement 'gender' was always a point of contestation. Still, the EU has participated with the UN in many programmes particularly under the theme of the 
WPS agenda and in 2015, appointed the Principal Advisor on Gender and on the implementation of UNSCR 1325 on WPS. The commitment in the EUGS thus seemed to underscore the commitment to integrate gender in the sphere of foreign and security policy.

However, the framework for implementation, and indeed the clear normative position of the EU on gender and foreign policy, had been absent until the adoption of the Council Conclusions and Strategic Approach on WPS in December 2018. This new EU framework builds on prior commitments and the impetus to implement EUGS thus representing a significant development. It is also worth noting that momentum at arriving at these conclusions picked up after the Brexit vote and consequently we know that UK official participation has been limited in the process leading up to the Council Conclusions and Strategic Approach, although UK civil society remains part of the community of EU civil society organisations involved in the process. In this section, we highlight Brexit as a critical moment with implications for future EU uptake of the WPS agenda as a normative framework for including gender perspectives in its foreign and security policies. Recalling our critical feminist lenses, it is apparent that whatever successes are measured in the context of development, it is such that the idea of 'gender equality' is deployed instrumentally where the EU already had leverage globally. Since the referendum and as plans for further defence and security cooperation have emerged at the Union, we have also observed the same momentum to develop the WPS agenda further in the EU27 context. We thus perceive the Council Conclusions and Strategic Approach to WPS as a culmination of efforts at the EU level to 'move on' without the UK contributing as a member state. It would seem then that Brexit has provided the opportunity for greater coherence on the part of the EU (see Zuleeg, 2014).

To illustrate this, we used NVivo to perform text searches to establish how the Strategic Approach frames the EU's (post-)Brexit WPS agenda. This further enables us to see if there has been a noticeable shift in the 'new' EU approach to WPS since the last policy was adopted 10 years previously. The drafting, re-drafting and adoption of the Strategic Approach has taken place during the process of Brexit. Consequently, it is worth evaluating the extent to which the process of the UK's departure has impacted on the normative agenda of the WPS framework.

Taking a critical feminist approach, we foregrounded our analysis in response to a key question: how does the Strategic Approach represent the WPS agenda? We identified proxies for gender and conducted a text search to see how the document understands women, men or gender in this framework. We included stemmed words in the search and did not include 'boys' or 'girls' in our search if there's already a reference to men or women. As Table 1 shows, the policy makes significantly more references to 'gender', than to 'women' or 'men'. This could suggest a move to widen the WPS agenda beyond women, and to include wider gender concerns. This represents some, albeit limited, progress in moving away from a conception of 'gender as women' when compared to the earlier Comprehensive Approach which made 26 references to 'men', compared to 191 to 'women' (Guerrina \& Wright, 2016, p. 309). Moreover, the Strategic Approach makes only three references to 'masculinity' and none to 'femininity'. All of these references are an attempt to define a 'positive masculinity' as one which is 'non-violent'. This reinforces the notion that the norm is a violent masculinity. Further, given that reference is made to women significantly more than it is to men, implicitly, it appears that gender is still strongly associated with women and less on the actual notion of gender relations and therefore gender understood as power.

The WPS agenda has been critiqued for presenting a false dichotomy of women as victims versus agents of change. Almost 20 years on from the first WPS UN resolution much has been written about this (see Muehlenhoff, 2017; Shepherd, 2011, 2016) and the eight follow-up resolutions passed by the Security Council go some way to ameliorating this concern. It is nevertheless pertinent to ask whether this shift has been incorporated into policy by the EU as the UK leaves the EU. Earlier analysis by Guerrina and Wright (2016, p. 308) suggested the EU had focused on women's agency in its early policy engagement with WPS. The Strategic Approach is a lengthier $(74 \%)$ and more detailed document than the policies it replaces adopted in 2008: the Comprehensive Approach to the EU implementation of the UN Security Council Resolutions 1325 and 1820 on WPS (43\%) and the Implementation of UNSCR 1325 as reinforced by UNSCR 1820 in the context of ESDP (15\%).

We again used critical content analysis to establish whether these tensions between victim and agent are ameliorated within the Strategic Approach. This involved manually coding all references to women identified in the text search of the Strategic Approach. Our findings (see Table 2) identify that in line with previous policy on WPS, the EU continues to emphasise women's agency over victimhood. As Guerrina and Wright (2016, p. 308) found, earlier EU policy engagement on WPS frames women as decision-makers almost $25 \%$ more than as victims (41 references, compared to 31). The 2008 Comprehensive Approach included a focus on women as mediators and chief negotiations representing a 'value added' approach to representation, with women

Table 1. Strategic Approach to WPS.

\begin{tabular}{lllllll}
\hline Gender & & Women & & Men & & Total \\
\hline Word count & Coverage & Word count & Coverage & Word count & Coverage & Words \\
\hline 341 & $1.94 \%$ & 161 & $0.92 \%$ & 52 & $0.30 \%$ & 17,564 \\
\hline
\end{tabular}


viewed as a resource for peacebuilding and conflict resolution (Guerrina \& Wright, 2016, p. 308). The Strategic Approach takes this a step further as Table 2 shows, with women framed almost $50 \%$ more as agents over victims. This appears to be a conscious effort with the policy identifying recognition of 'women's agency over victimhood as a first step to engaging meaningfully and equitably with women from fragile settings.'

Table 2. Framings of women in the Strategic Approach.

\begin{tabular}{lr}
\hline Frame & Count \\
\hline Agents & 110 \\
Victims & 54 \\
\hline
\end{tabular}

Overall, the Strategic Approach represents significant progress in the EU's engagement with WPS. It goes beyond some of the essentialising tropes embedded in earlier policy iterations and extends WPS considerations to include a wide range of applicable areas, including social media and an emphasis on listening to different women's voices. Unsurprisingly, the policy is centred around the EU's values. For example, the inclusion of gender equality in employment policy has mapped onto the EU's 'promarket-forming activities of the neoliberal governance structure' (Young, 2000, p. 77). In foreign policy, this has translated in a strong focus on women's agency, over considering their specific needs in conflict and post-conflict settings (see Table 2). Women's agency is framed through the lens of (economic) empowerment, with it justified as adding value to the overarching policy objectives and strategy. Women's empowerment is also contingent and pursed 'in accordance with its [the EU's] values and principles' (Council of the European Union, 2018). We see again then a focus on 'women [presented] as neoliberal subjects who are responsible for their own emancipation' (Muehlenhoff, 2017). However, the Strategic Approach also engaged with more nuanced accounts of women's agency, for example, stating that 'women should not be presumed to be peacemakers' (Council of the European Union, 2018). And while it acknowledges that women are not a homogenous group, and the EU should actively seek to consult beyond 'elite urban women', a broader critical reading finds these tropes are not challenged consistently in the policy document and are in fact reinforced in certain places. These two quotes from the Strategic Approach are indicative of this:

Women's meaningful and equitable participation is both critical for effective prevention policies and their implementation.

Empowering women as drivers of economic growth strengthens societal resilience. (Council of the European Union, 2018)

The EU's post-Brexit engagement with WPS undoubtedly represents a significant development on previous policy iterations. A product of a two-year post-referendum con- sultation and negotiation that included the experience of UK actors (including both government officials and civil society) but mainly focused on the future of the EU27. It is a more nuanced and reflective policy, and one that seeks to provide the EU with agency on WPS apart from its member states. It also highlights the increased confidence of the institutions to develop and take ownership of this particular policy portfolio.

\section{Conclusions}

The campaign of the UK to leave the EU has implications for governance in the EU. Brexit is more than a singular event but should be understood as a continuous process in which EU actors continue to propose and enact policies with the UK simultaneously present and absent. De Ville and Siles-Brügge (2019) already refer to this as the dynamic impact of Brexit. At the same time, as we show, Brexit as a process has either ignored gender or taken it for granted in the same way that the future of security/defence cooperation is approached. By looking at this together, particularly in light of the EU's renewed commitment to gender in its foreign and security policy, we have examined the extent to which this process can impact on the ambitions of the EU as a foreign and security actor, and a more visible actor in the WPS field. As a member state of the EU, the UK has shown a specific type of gender awareness in foreign policy leadership which it has sought to lead on in the regional context of the EU and NATO. While some of the UK's assumptions about women and gender were replicated at the EU level, there is also a discursive shift in the post 2016 discourse borne out in the Strategic Approach. The process of developing this has not excluded the UK and the possibility of future cooperation is there. Indeed, both the UK and EU have used WPS as tool to engage external actors and so this might provide one less avenue for friction. Yet, the almost complete absence of gender from the Withdrawal Agreement suggests gender will not form a locus of the UK-EU's future relations once the UK has left the Union. Moreover, this research shows that while there is indication that the EU has evolved in its understanding of gender and thus the transformative potential of the WPS agenda, this is happening in parallel to other development in foreign and security policy (see Smith, 2019). Specifically, as the EUGS makes a call for greater gender inclusivity, it also does to further defence cooperation and militarism. Given this state of affairs, the practice of the EU as a gender foreign and security actor may fall short of transformation for those impacted by EU policies post-Brexit.

\section{Acknowledgments}

We would like to thank the Editors and the two anonymous reviewers for their very thorough engagement and insightful comments helped us in improving the article. Any error contained here is however ours. 


\section{Conflict of Interests}

The authors declare no conflict of interests.

\section{References}

Achilleos-Sarll, C., \& Martill, B. (2019). Toxic masculinity: Militarism, deal-making and the performance of Brexit. In D. Moira, N. Ferreria, \& S. Millns (Eds.), Gender and queer perspectives on Brexit. Basingstoke: Palgrave Macmillan.

Annesley, C., \& Gains, F. (2013). Investigating the economic determinants of the UK gender equality policy agenda. The British Journal of Politics \& International Relations, 15(3), 125-146.

Bain, J., \& Masselot, A. (2012). Gender equality law and identity building for Europe. Canterbury Law Review, 18, 97-117.

Council of the European Union. (2018). Women, peace and security: Council conclusions (No. 15086/18). Brussels: Council of the European Union. Retrieved from https://www.consilium.europa.eu/ media/37412/st15086-en18.pdf

Cox, R. W. (1981). Social forces, states and world orders: Beyond international relations. Millennium: Journal of International Studies, 10(2), 126-155.

Danisi, C., Dustin, M., \& Ferreira, N. (2017). Queering Brexit. The UK in a changing Europe. Retrieved from http://ukandeu.ac.uk/queering-brexit

Davies, S. E., \& True, J. (2017). Norm entrepreneurship in foreign policy: William Hague and the prevention of sexual violence in conflict. Foreign Policy Analysis, 13(3), 701-721.

Debusscher, P. (2011). Mainstreaming gender in European commission development policy: Conservative Europeanness? Women's Studies International Forum, 34(1), 39-49.

De Ville, F., \& Siles-Brügge, G. (2019). The impact of Brexit on EU trade policy. Politics and Governance, 7(3), 7-18.

Emejulu, A. (2016). On the hideous whiteness of Brexit: 'let us be honest about our past and our present if we truly seek to dismantle white supremacy'. Verso. Retrieved from www.versobooks.com/blogs/ 2733-on-the-hideous-whiteness-of-brexit-let-usbe-honest-about-our-past-and-our-present-if-wetruly-seek-to-dismantle-white-supremacy

Equality and Human Rights Commission. (2018). Pressing for progress: Women's rights and gender equality in 2018. Retrieved from https://www.equalityhuman rights.com/sites/default/files/pressing-for-progresswomens-rights-and-gender-equality-in-2018-pdf.pdf

European Union. (2019). NATO-EU cooperation on women, peace and security in the Western Balkans. Delegation of the European Union to Bosnia and Herzegovina. Retrieved from https://europa.ba/?p= 62353

Fagan, C., \& Rubery, J. (2018). Advancing gender equality through European employment policy: The impact of the UK's EU membership and the risks of Brexit. Social Policy and Society, 17(2), 297-317

Galpin, C. (2018). Women have been excluded from the Brexit debate. UK in a changing Europe. Retrieved from http://ukandeu.ac.uk/women-have-beenexcluded-from-the-brexit-debate

Guerrina, R. (2005). Mothering the Union: Gender politics in the EU. Manchester: Manchester University Press.

Guerrina, R. (2019). Hyper-masculinity in Brexit is stopping us from finding another way forward. i news. Retrieved from https://inews.co.uk/opinion/comment/ brexit-hyper-masculinity-limited-opportunitiesalternative-ways-forward

Guerrina, R., Chappell, L., \& Wright, K. A. M. (2018). Transforming CSDP? Feminist triangles and gender regimes. JCMS: Journal of Common Market Studies, 56(5), 1036-1052.

Guerrina, R., Haastrup, T., Wright., K. A. M., Masselot, A., MacRae, H., \& Cavaghan, R. (2018). Does European studies have a gender problem? Experiences from researching Brexit. International Feminist Journal of Politics, 20(2), 252-257.

Guerrina, R., \& Masselot, A. (2018). Walking in the shadow of EU law: Unpacking the gendered consequences of Brexit. Social Policy and Society, 17(2), 319-330.

Guerrina, R., \& Wright, K. A. M. (2016). Gendering normative power Europe: Lessons of the women, peace and security agenda. International Affairs, 92(2), 293-312.

Haastrup, T. (2017). The undoing of a unique relationship? Peace and security in the EU-South Africa strategic partnership. South African Journal of International Affairs, 24(2), 197-213.

Haastrup, T. (2018). Creating Cinderella? The unintended consequences of the women peace and security agenda for the EU's mediation architecture. International Negotiation, 23(2), 218-237.

Haastrup, T., Wright, K. A. M., \& Guerrina, R. (2016). Women in the Brexit debate: Still largely confined to 'low politics'. LSE Impact Blog. Retrieved from http:// blogs.Ise.ac.uk/brexit/2016/06/17/women-in-thebrexit-debate-still-largely-confined-to-low-politics

Hantrais, L. (2018). Assessing the past and future development of EU and UK social policy. Social Politics and Society, 17(2), 265-279.

Henry, M. G. (2018). Why critical military studies needs to smash imperial white supremacist capitalist heteropatriarchy: A rejoinder. Critical Military Studies, 2018, 1-4.

Holvikivi, A. (2019). Gender experts and critical friends: Research in relations of proximity. European Journal of Politics and Gender, 2(1), 131-147.

Hozić, A. A., \& True, J. (2017). Brexit as a scandal: Gender and global Trumpism. Review of International Political Economy, 24(2), 270-287.

Kantola, J. (2010). Gender and the European Union. Bas- 
ingstoke: Palgrave Macmillan

Kronsell, A. (2016a). Sexed bodies and military masculinities: Gender path dependence in EU's common security and defence policy. Men and Masculinities, 19(3), 311-336.

Kronsell, A. (2016b). The power of EU masculinities: A feminist contribution to European integration theory. JCMS: Journal of Common Market Studies, 54(1), 104-120.

Lombardo, E. (2018). Gendered effects of the European disintegration and integration processes. Paper presented at the UACES Conference, University of Bath, UK.

MacKinnon, C. (1987). Feminism unmodified: Discourses on life and law. Cambridge, MA: Harvard University Press.

MacLeavy, J. (2018). Leave-voting men, Brexit and the crisis of masculinity. LSE Brexit Blog. Retrieved from https://blogs.Ise.ac.uk/brexit/2018/10/24/leavevoting-men-brexit-and-the-crisis-of-masculinity

MacRae, H. (2010). The EU as a gender equality polity: Myths and realities. Journal of Common Market Studies, 48(1), 153-172.

Marinaki, M. [MaraMarinakiEU]. (2019, January 14). \#EU joins \#NATO \#UN to compare notes on our policies on preventing and responding to \#SEA Sexual Exploitation \& Abuse [Tweet]. Retrieved from https://twitter.com/MaraMarinakiEU/status/ 1084781328426586112

Muehlenhoff, H. L. (2017). Victims, soldiers, peacemakers and caretakers: The neoliberal constitution of women in the EU's security policy. International Feminist Journal of Politics, 19(2), 153-167.

Nadibaidze, A. (2019). EU foreign policy after Brexit: The debate over decision-making rules continues. Open Europe. Retrieved from https://openeurope.org.uk/ today/blog/eu-foreign-policy-after-brexit-thedebate-over-decision-making-rules-continues

O'Dwyer, M. (2018). The intersectional politics of bullshit. European Journal of Politics and Gender, 1(3), 405-420.

Plomien, A. (2018). EU social and gender policy beyond Brexit: Towards the European pillar of social rights. Social Policy and Society, 17(2), 281-296.

Ritch, E. (2019). Foreboding newness: Brexit and feminist civil society in Scotland. In M. Dustin, N. Ferreira, \& S. Millns (Eds.), Gender and queer perspectives on Brexit (pp. 333-362). Cham: Springer.

Shepherd, L. J. (2011). Sex, security and superhero(in)es: From 1325 to 1820 and beyond. International Feminist Journal of Politics, 13(4), 504-521.

Shepherd, L. J. (2016). Victims of violence or agents of change? Representations of women in UN peacebuilding discourse. Peacebuilding, 4(2), 121-134.

Short, K. G. (2016). Critical content analysis as a research methodology. In H. Johnson, J. Mathis, \& K.
Short (Eds.), Critical content analysis of children's and young adult literature (pp. 1-15). New York, NY: Routledge.

Sjoberg, L. (2010). Introduction. In L. Sjoberg (Ed.), Gender and international security: Feminist perspectives (pp. 1-14). Oxford: Routledge.

Smith, M. (2019). The European Union and the global arena: In search of post-Brexit roles. Politics and Governance, 7(3), 83-92.

Utt, J., \& Short, K. G. (2018). Critical content analysis: A flexible method for thinking with theory. Understanding and Dismantling Privilege, 8(2), 1-7.

Van Eerdewijk, A., \& Roggeband, C. (2014). Gender equality norm diffusion and actor constellations: A first exploration. In A. van der Vleuten, A. van Eerdewijk, \& C. Roggeband (Eds.), Gender equality norms in regional governance: Transnational dynamics in Europe, South America and southern Africa (pp. 42-64). Basingstoke: Palgrave Macmillan.

Virdee, S., \& McGeever, B. (2017). Racism, crisis, Brexit. Ethnic and Racial Studies, 41(10), 1802-1819.

Wagnsson, C. (2011). A security community in the making? Sweden and NATO post-Libya. European Security, 20(4), 585-603.

Walby, S. (2004). The European Union and gender equality: Emergent varieties of gender regime. Social Politics: International Studies in Gender, State \& Society, 11(1), 4-29.

Williams, K. (2017). Feminism in foreign policy. In Oxford research encyclopaedia of politics (pp 1-23). New York, NY: Oxford University Press.

Willis, A. I., Montavon, M., Hunter, C., Hall, H., Burke, L., \& Herrera, A. (2008). On critically conscious research: Approaches to language and literacy research. New York, NY: Teacher's College Press.

Wright, K. A. M. (2016). NATO's adoption of UNSCR 1325 on women, peace and security: Making the agenda a reality. International Political Science Review, 37(3), 350-361.

Wright, K. A. M., Hurley, M., \& Gil Ruiz, J. I. (2019). NATO, gender and the military: Women organising from within. London: Routledge.

Wright, S. (2010). Feminist theory and arms control. In L. Sjoberg (Ed.), Gender and international security: Feminist perspectives (pp. 191-213). Oxford: Routledge.

Young, B. (2000). Disciplinary neoliberalism in the European Union and gender politics. New Political Economy, 5(1), 77-98.

Zuleeg, F. (2014). The view for Brussels. In A. Möller, \& T. Oliver. The United Kingdom and the European Union: What would a 'Brexit' mean for the EU and other States around the World? (DGAP-Analyse, No. 16). Berlin: Forschungsinstitut der Deutschen. Retrieved from https://nbn-resolving.org/urn:nbn:de: 0168-ssoar-55608-3 


\section{COGITATIO}

\section{About the Authors}

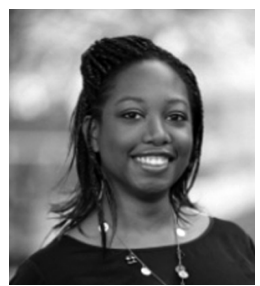

Toni Haastrup (Dr.) is Senior Lecturer in International Politics at the University of Stirling. Her research examines the gender dynamics at play within regional security institutions, particularly the African and European Unions. Her current work focuses on the regional practices of implementing the WPS agenda. She is the author of Charting Transformation through Security: Contemporary EU-Africa Relations (Palgrave, 2013) and joint Editor in Chief of the JCMS: Journal of Common Market Studies.

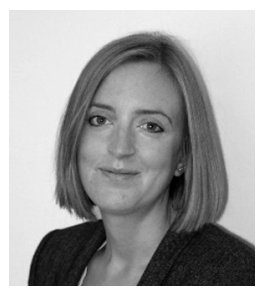

Katharine A. M. Wright (Dr.) is a Lecturer in International Politics at Newcastle University. Her research explores the intersection of gender and security in institutional settings, including the engagement of NATO and the EU with UN Security Council Resolution 1325 and the WPS agenda. She is the author of NATO, Gender and the Military: Women Organising from within (with Matthew Hurley and Jesus Ignacio Gil Ruiz, Routledge, 2019).

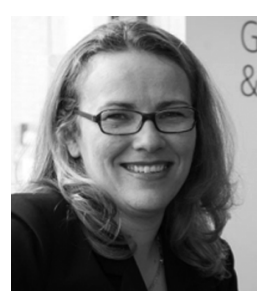

Roberta Guerrina is Professor in Politics and Director of the Gender Research Centre at the University of Bristol. She is a specialist in the politics of gender, with a particular interest in EU politics and social policy, citizenship and gender equality and has published extensively in these areas. In addition, authoring Mothering the Union (Manchester University Press, 2005) her work has appeared in leading disciplinary journals like Journal of Common Market Studies, International Affairs, Women's Studies International Forum, and Review of International Studies. She is currently joint editor of the Journal Common Market Studies Annual Review. 